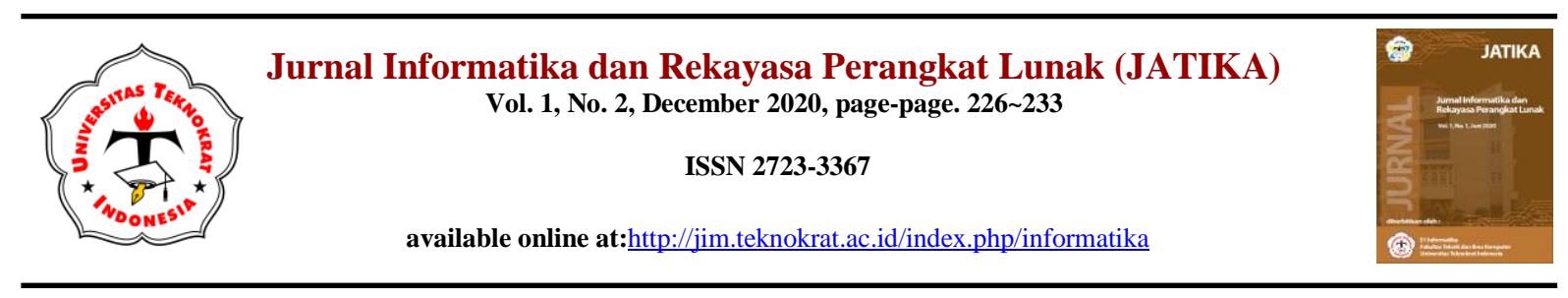

\title{
IMPLEMENTASI ALGORITMA APRIORI UNTUK ANALISIS PENJUALAN KONTER BERBASIS WEB
}

\author{
Jala Roza Gumilang \\ S1 Informatika, Universitas Teknokrat Indonesia \\ rozagumilang2@gmail.com
}

Received: (date month year)Accepted: (date month year) Published: (date month year )

\begin{abstract}
Effective promotion can increase sales figures. In order to determine and develop promotions to be more targeted and targeted, the counter needs to identify the target market and buying motives. One way to identify market conditions is to determine consumer purchase interest, which can be observed through purchase transaction data. A priori algorithm can be used in the sales process, by providing a relationship between sales data, in this case, the quotas or cellphone accessories purchased so that consumer purchasing patterns will be obtained. The counter can use the information to take appropriate business action, in which case the information can be taken into consideration in determining the next sales strategy. By using data mining methods, namely market basket analysis and a priori algorithm, an association rule is generated that shows the consumer's buying patterns and how strongly an item affects other items. From the results of the analysis and testing, the system has been tested three times using transaction data for the G Cell Counter during the period December 2019 to November 2020 (1 year) by changing the minimum support and minimum confidence parameters, then the result is a menu item combination that can be made for the process. promotion development.
\end{abstract}

Keywords: Keyword one, keyword two, keyword three, keyword four, keyword five - Times New Roman, 9 pt, single spacing (no more than two lines)

\begin{abstract}
Abstrak
Promosi yang efektif dapat meningkatkan angka penjualan. Untuk menentukan dan mengembangkan promosi agar lebih terarah dan tepat sasaran, Konter perlu mengidentifikasi pasar sasaran dan motif membeli. Salah satu cara untuk mengenali kondisi pasar adalah mengetahui minat beli konsumen, yang dapat diamati melalui data-data transaksi pembelian. Algoritma apriori dapat dimanfaatkan dalam proses penjualan, dengan memberikan hubungan antar data penjualan, dalam hal ini adalah kuota atau aksesoris handphone yang di beli sehingga akan didapat pola pembelian konsumen. Pihak konter dapat memanfaatkan informasi tersebut untuk mengambil tindakan bisnis yang sesuai, dalam hal ini informasi dapat menjadi bahan pertimbangan untuk menentukan strategi penjualan selanjutnya. Dengan menggunakan metode data mining yaitu market basket analysis dan algoritma apriori, dihasilkan aturan asosiasi yang menunjukkan pola beli konsumen dan seberapa kuat suatu item mempengaruhi item lain. Dari hasil analisa dan pengujian telah dilakukan ujicoba sistem sebanyak tiga kali menggunakan data transaksi Konter G Cell selama periode bulan Desember 2019 sampai November 2020 (1 Tahun) dengan merubah parameter minimum support dan minimum confidence maka didapat hasil kombinasi menu item yang dapat di buat untuk proses pengembangan promosi.
\end{abstract}

(one blank single space line, 10 point font).

Kata Kunci: terdiri dari 5 kata kunci $(\mathbf{9}$ pt)

\section{To cite this article:}

Jala Roza Gumilang. (2020). IMPLEMENTASI ALGORITMA APRIORI UNTUK ANALISIS PENJUALAN KONTER BERBASIS WEB. Jurnal Informatika dan Rekayasa Perangkat Lunak, Vol(1) No(2), 226-233. 


\section{PENDAHULUAN}

Usaha di bidang konter saat ini sangat di gandrungi banyak orang. Terutama yang mengedepankan penjualan kuota dan aksesoris handphone.Di era digital sekarang ini memang hal yang wajar bagi setiap orang untuk membeli kuota karena kuota sekarang ini sudah menjadi kebutuhan pokok bagi setiap orang. Salah satu konter yang mengedepankan penjualan kuota adalah Konter G Cell. Bila dilihat dari barang yang di jual konter G Cell, dapat kita lihat bahwa penjualan yang di fokuskan adalah penjualan kuota dan aksesoris handphone.

Mencari keuntungan merupakan tujuan dari Konter, sehingga untuk memenuhi tujuan operasional dengan tetap mempertahankan aktivitas operasional dalam dunia bisnis yang kompetitif diperlukan strategi yang dapat meningkatkan penjualan (Setiawansyah, Sulistiani and Darwis, 2020), (Eka, Putri and Surahman, 2020). Di sisi lain, minat beli konsumen juga dipengaruhi oleh beberapa faktor. Tidak mudah membangkitkan minat membeli sebelum konsumen akhirnya memutuskan untuk membeli suatu produk. Dengan adanya promosi maka masyarakat yang sebelumnya tidak tertarik untuk membeli suatu produk akan menjadi tertarik dan mencoba produk tersebut agar konsumen melakukan pembelian.

Untuk menentukan dan mengembangkan promosi agar lebih tepat sasaran dan tepat sasaran, salah satu caranya adalah dengan mengetahui selera dan kebutuhan pembelian konsumen yang dapat diamati melalui data transaksi pembelian. Terkadang hasil pengolahan data sederhana (query) tidak mendapatkan hasil yang efektif karena banyaknya volume data yang diolah dan sulitnya melihat keterkaitan antara penjualan satu barang dengan barang lainnya. Untuk itu perlu adanya suatu sistem dapat membantu dengan cepat dan tepat. Pemanfaatan informasi dan pengetahuan yang terkandung dalam sejumlah besar data saat ini dikenal dengan istilah data mining (Suryanata, Pane and Hutasuhut, 2019).

Data mining merupakan istilah yang digunakan untuk mendeskripsikan penemuan pengetahuan dalam suatu database atau sering disebut Knowledge Discovery in Database (KDD). Penerapan Algoritma Apriori membantu dalam pembentukan kombinasi item kandidat yang mungkin terjadi, kemudian dilakukan pengujian apakah kombinasi tersebut memenuhi parameter support dan confidence minimum yang merupakan nilai threshold yang diberikan oleh pengguna (Suryanata, Pane and Hutasuhut, 2019). Algoritma apriori termasuk jenis aturan asosiasi pada data mining. Aturan yang menyatakan asosiasi antara beberapa atribut sering disebut affinity analysis atau market basket analysis. Analisis asosiasi atau penambangan aturan asosiasi adalah teknik penambangan data untuk menemukan aturan untuk kombinasi item (Prasetyawan et al., 2018)

\section{TELAAH PUSTAKA \\ Data Mining}

Data mining diartikan sebagai proses menemukan pola dalam data, dimana proses tersebut harus otomatis atau semi otomatis. Pola yang ditemukan harus bermakna dan menguntungkan, terutama manfaat ekonomis dari Ian H Witten, Eibe Frank, dan Mark A Hall, "Data Mining: Alat Praktis untuk Pembelajaran dan Rekayasa Mesin" Edisi Ketiga (Rahmawati and Merlina, 2018)

Penambangan data adalah teknik pencarian dan analisis data yang sangat baik yang dapat digunakan untuk menemukan pola dan aturan yang bermakna. Pola yang diharapkan dapat diperoleh dari berbagai database relasional, data warehouse, data transaksi dan data berorientasi objek. Dapat disimpulkan dari pernyataan sebelumnya bahwa data mining selalu terkait dengan penemuan informasi atau pengetahuan baru secara otomatis atau semi-otomatis dalam database (Sintaro, Surahman and Prastowo, 2020).

\section{Algoritma Apriori}

Algoritma Apriori adalah algoritma yang dapat digunakan untuk menerapkan analisis keranjang pasar untuk menemukan aturan asosiasi yang memenuhi batas dukungan dan kepercayaan. Pada tahap pertama, algoritma melakukan ekstraksi sistematis tanpa mengeksplorasi semua kandidat, dan tahap kedua, melakukan ekstraksi aturan yang kuat. Frequent itemsets biasanya mengacu pada kumpulan item yang sering muncul bersamaan dalam data transaksi. Misalnya, jika barang A dan B sering dibeli bersama di toko. Setelah menemukan frequent itemset, algoritma ini akan menguji pengetahuan tentang frequent itemset sebelumnya untuk menggali lebih banyak informasi. Apriori menggunakan pendekatan berulang.

Prinsip kerja dasar dari algoritma ini adalah mengembangkan kumpulan item yang sering. Mulailah dengan satu proyek, dan kemudian secara rekursif mengembangkan kumpulan item yang sering menjadi dua proyek, tiga item, dan seterusnya, hingga kumpulan item yang sering tidak lagi dikembangkan.

Untuk mengembangkan frequent item set yang terdiri dari dua item, satu item dapat digunakan, karena jika satu set item tidak dapat mencapai minimum support, maka setiap item set yang lebih besar tidak akan melebihi minimum support (Iswandi, Permana and Salisah, 2020). 


\section{METODE PENELITIAN \\ Kerangka Penelitian}

Kerangka penelitian adalah suatu rancangan alur sebuah penelitian yang terstruktur disampaikan melalui gambar yang berurutan sesuai dengan tahapan apa saja yang akan dilakukan dalam melakukan suatu penelitian (Budiman, Wahyuni and Bantun, 2019). Adapun kerangka penelitian yang digunakan secara keseluruhan dapat dilihat pada Gambar 1

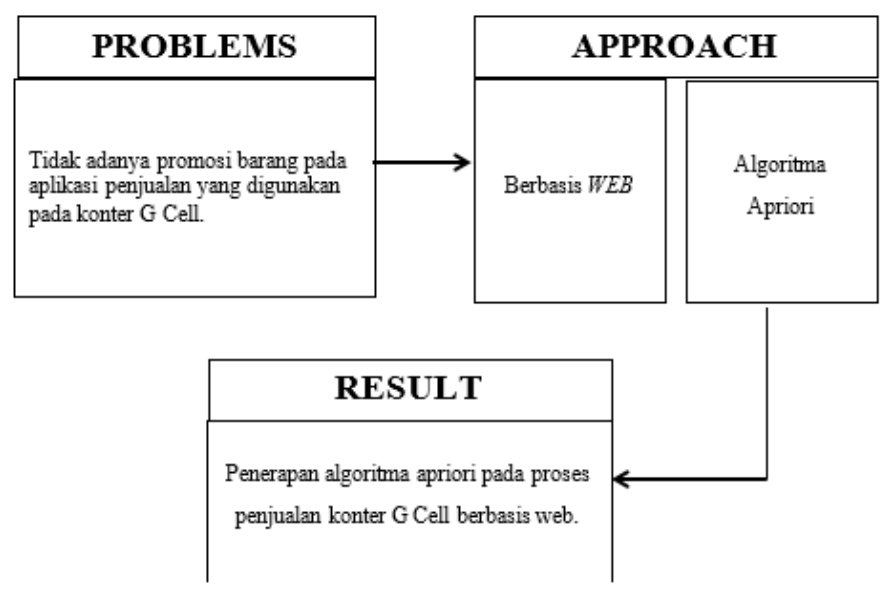

Gambar 1. Kerangka Penelitian

Kerangka penelitian diatas terdapat masalah yaitu Masalah yang ditemukan pada aplikasi penjualan konter G Cell adalah tidak adanya system promosi dan system peletakan barang pada aplikasi tersebut sehingga menyulitkan sang pemilik konter untuk menjual barang yang sulit laku dan menyusun barang-barang ager terlihat rapi dan menarik konsumen. Pendekatan dalam penelitian adalah cara yang dilakukan penulis untuk menerapkan algoritma yang digunakan dalam penelitian. Penulis menerapkan algoritma apriori dalam aplikasi penjualan yang akan dibangun berbasis web. Hasil dari penelitian ini adalah sistem penjualan pada konter G Cell dapat tersusun rapi dan sang pemilik dapat melakukan promosi pada barang yang sulit laku karna algoritma ini dapat merekomendasikan barang yang berhubungan dengan barang yang dibeli konsumen.

\section{Teknik Pengumpulan Data}

Wawancara merupakan teknik pengumpulan data yang dilakukan melalui tatap muka dan tanya jawab langsung antara peneliti dan narasumber atau sumber data. Wawancara dalam penelitian ini dilakukan dengan ibu Nurul Uta Vinanti

\section{Analisis Kebutuhan Fungsional}

Tahap kebutuhan fungsional ini diperlukan untuk mengindikasi apa saja yang dibutuhkan dan diinginkan sistem oleh pengguna dari aplikasi penjualan konter G Cell adapun kebutuhan fungsional adalah sebagai berikut :

1. Admin
a. Dapat melakukan login.
b. Dapat menambah data barang.
c. Dapat mengubah data barang.
d. Dapat menghapus data barang.
e. Dapat membuat user.
f. Dapat menghapus user.
g. Dapat mengubah user.
h. Dapat mencetak laporan penjualan.
i. Dapat mencetak data barang.
j. Dapat melihat daftar transaksi dataset. 
k. Dapat memasukkan daftar transaksi dataset.

1. Dapat mengunduh daftar transaksi dataset.

m. Dapat menghapus daftar transaksi dataset.

n. Dapat melihat hasil aturan asosiasi dataset menu item.

o. Dapat menghitung algoritma apriori

p. Dapat melakukan logout.

2. Kasir
a. Dapat melakukan login.
b. Dapat melakukan transaksi penjualan.
c. Dapat mencetak laporan penjualan.
d. Dapat melakukan Logout.

\section{Usecase Diagram}

Usecase diagram pada sistem penjualan konter G Cell berbasis web adalah

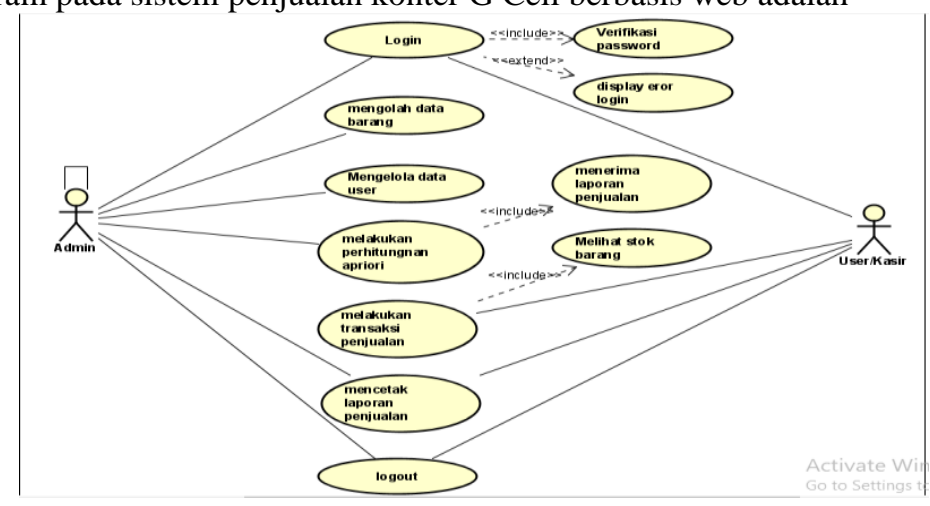

Gambar 2. Usecase Diagram

\section{HASIL DAN PEMBAHASAN}

\section{Halaman Login}

Halaman login merupakan tampilan yang digunakan sebagai sebagai hak akses ke halaman menu, berikut adalah tampilan login pada gambar 3 dibawah ini :

\section{G CELL}

Welcome

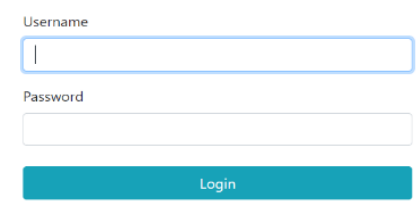

Gambar 3. Halaman Login 


\section{Halaman Dashboard}

Implementasi dashboard admin merupakan tampilan yang digunakan untuk menampilkan data penjualan pada admin, berikut adalah halaman dashboard admin pada pada gambar 4 dibawah ini :

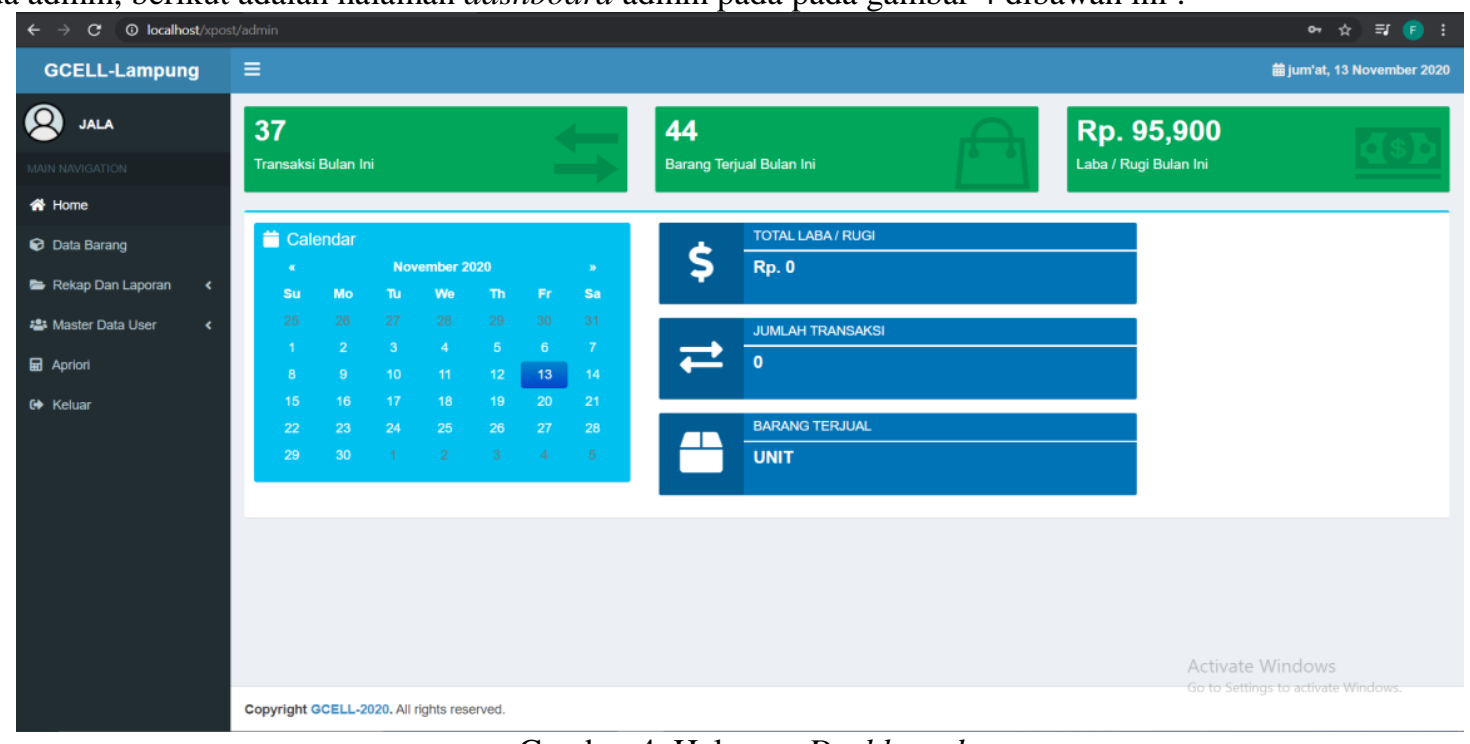

Gambar 4. Halaman Dashboard

\section{Halaman Barang}

Implementasi data barang merupakan tampilan yang digunakan untuk menampilkan data barang yang di gunakan untuk mengapus dan menambah barang, berikut adalah halaman data barang pada gambar 5 dibawah ini :

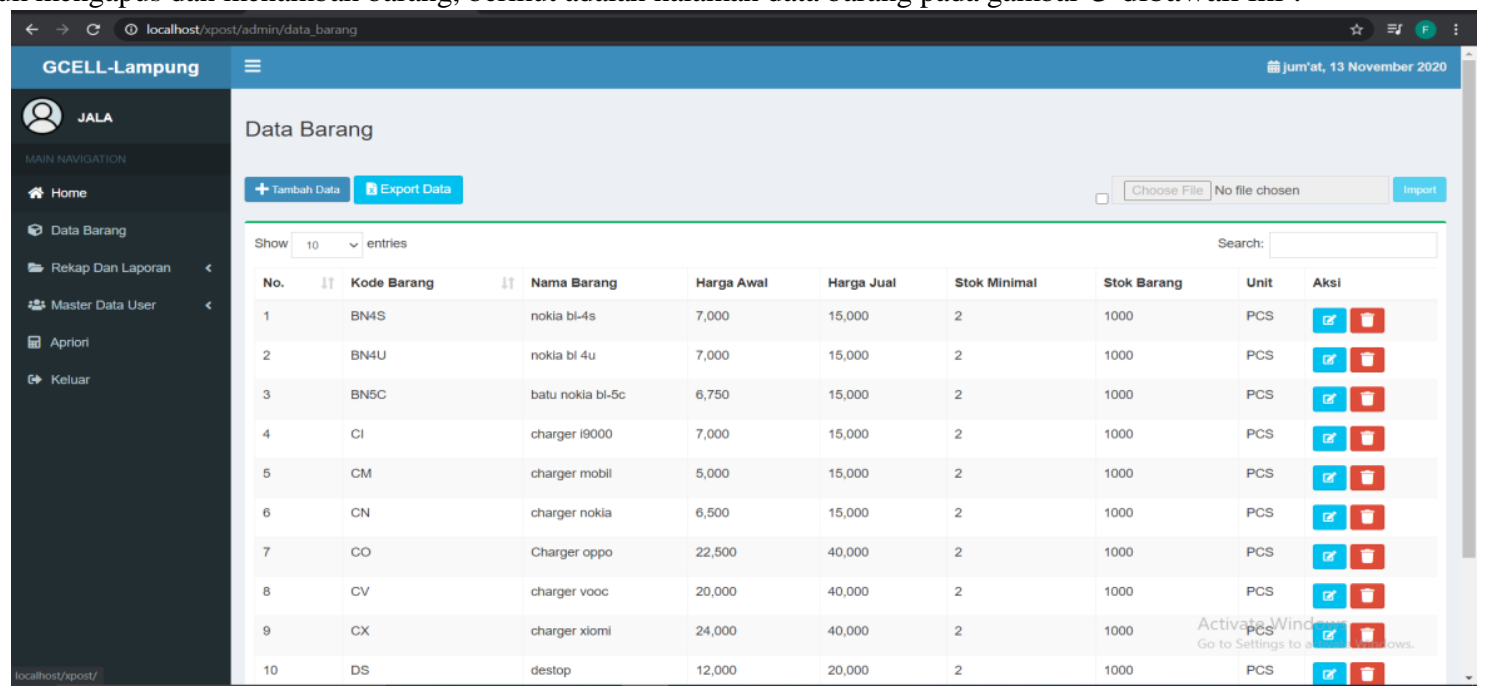

Gambar 5. Halaman Barang

\section{Halaman Rekap Penjualan}

Implementasi rekap barang merupakan tampilan yang digunakan untuk menampilkan laporan barang yang akan habis, berikut adalah halaman rekap barang pada gambar 6 dibawah ini : 


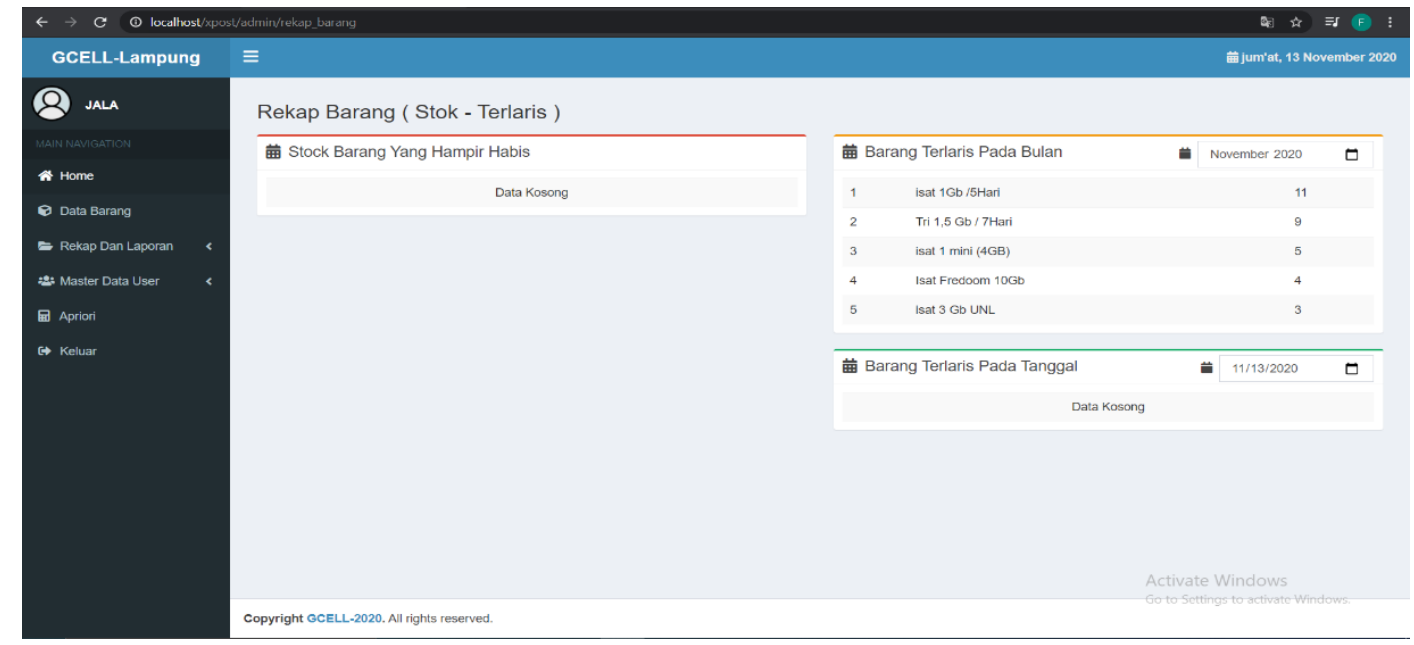

Gambar 6. Halaman Rekap Penjualan

\section{Halaman Apriori}

Halaman Implementasi proses apriori merupakan tampilan yang digunakan untuk menampilkan proses perhitungan apriori, berikut adalah halaman proses apriori pada gambar 7 dibawah ini :

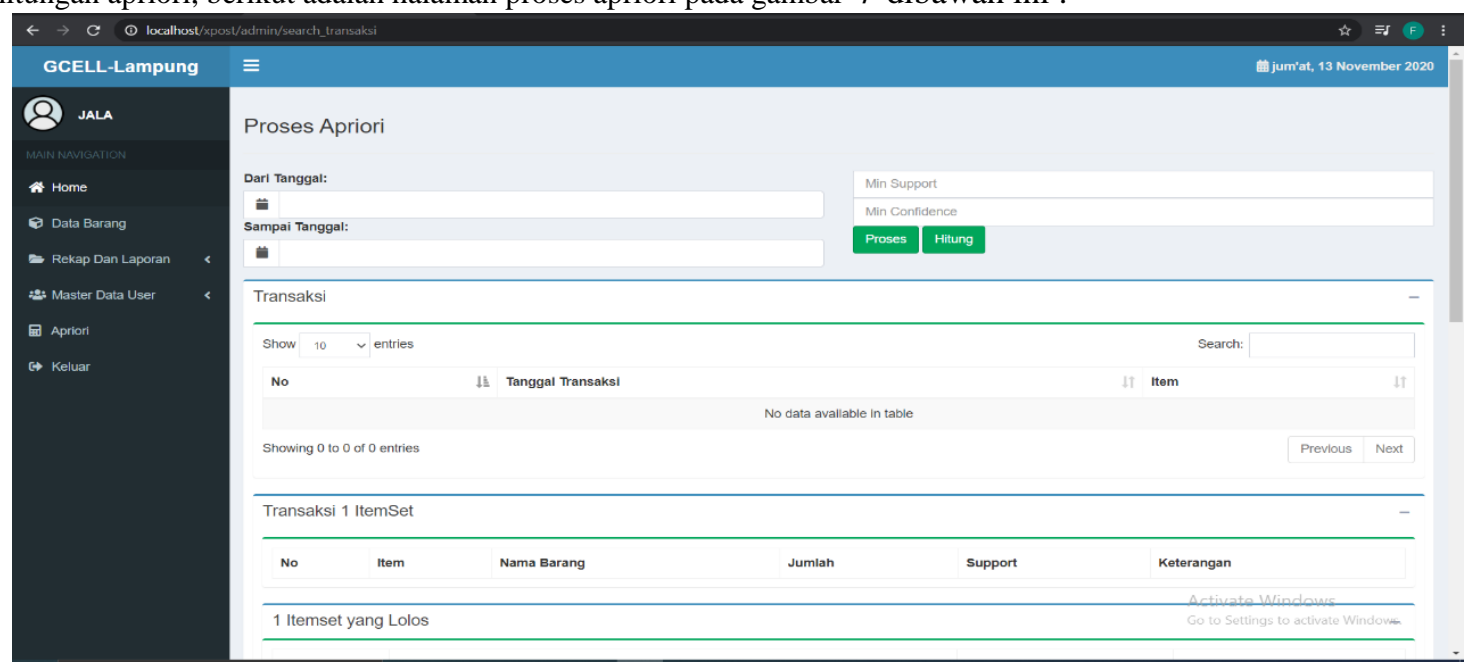

Gambar 7. Halaman Apriori

\section{Hasil Apriori}

Hasil dari implementasi sistem pola pencarian asosiasi barang. Pada percobaan ini melakukan ujicoba sistem dengan mengunakan data transaksi konter G Cell selama periode bulan Desember 2019 sampai November 2020 (1 tahun) memiliki jumlah transaksi sebanyak 326 .

\section{a. Hasil Percobaan Pertama}

Pada percobaan pertama mengunakan data transaksi konter G Cell selama periode bulan Desember 2019 sampai November 2020 (1 Tahun) dengan parameter nilai minimum support sebesar $85 \%$ dan nilai minimum confidence sebesar $85 \%$. Dari percobaan di atas dihasilkan enam aturan asosiasi yang terbentuk, dengan semua aturan yang lolos confidence. 


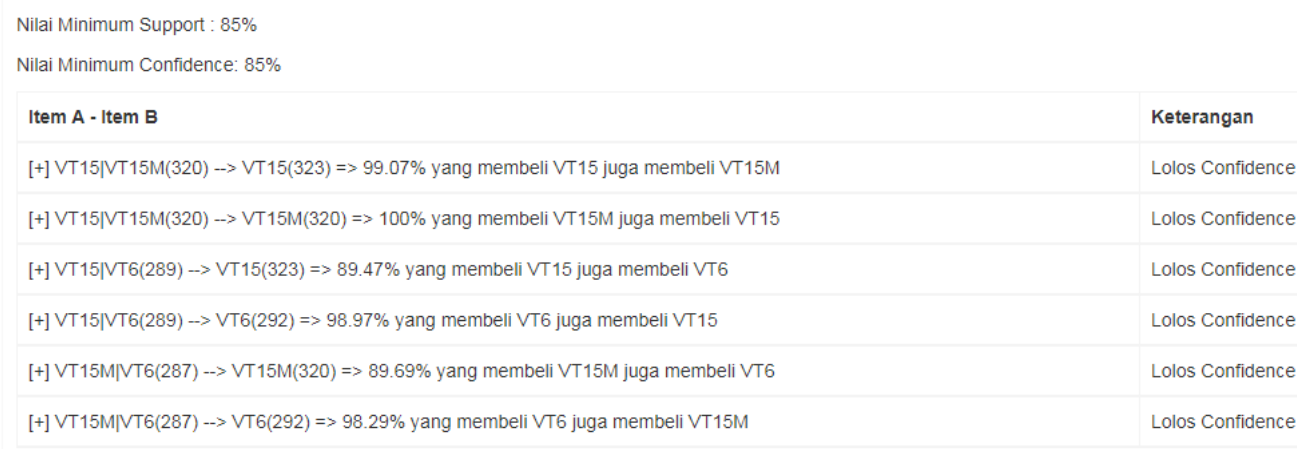

\section{Gambar 8. Hasil Apriori}

\section{b. Hasil PercobaanKedua}

Pada percobaan kedua mengunakan data transaksi konter G Cell selama periode bulan Desember 2019 sampai November 2020 (1 Tahun) dengan parameter nilai minimum support sebesar $85 \%$ dan nilai minimum confidence sebesar $90 \%$. Dari percobaan di atas dihasilkan enam aturan asosiasi yang terbentuk, dengan sempat aturan yang lolos confidence.

\section{c. Hasil Percobaan Ketiga}

Pada percobaan ketiga mengunakan data transaksi konter G Cell selama periode bulan Desember 2019 sampai November 2020 (1 Tahun) dengan parameter nilai minimum support sebesar $90 \%$ dan nilai minimum confidence sebesar $90 \%$

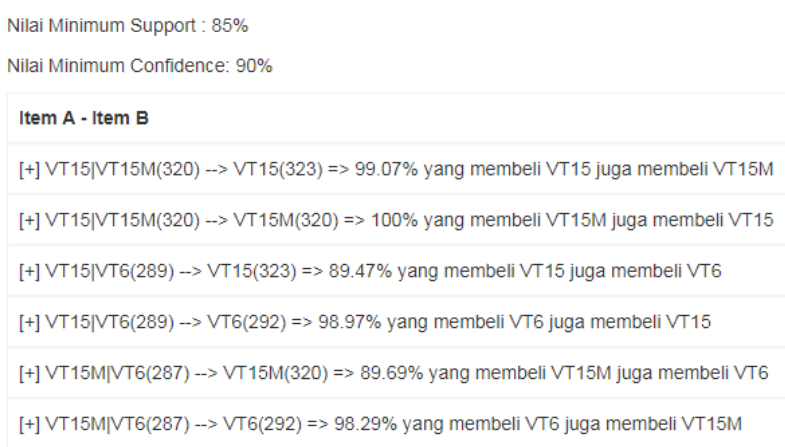

\begin{tabular}{l} 
Keterangan \\
\hline Lolos Confidence \\
\hline Lolos Confidence \\
\hline Tidak Lolos Confidence \\
\hline Lolos Confidence \\
\hline Tidak Lolos Confidence \\
\hline Lolos Confidence \\
\hline
\end{tabular}

Gambar 9. Hasil Apriori

Nilai Minimum Support : $90 \%$

Nilai Minimum Confidence: $90 \%$

Item A - Item B

Keterangan

$[+] \mathrm{VT} 15 \mid \mathrm{VT} 15 \mathrm{M}(320) \rightarrow \mathrm{VT} 15(323) \Rightarrow>99.07 \%$ yang membeli VT15 juga membeli VT15M

Lolos Confidence

$[+]$ VT15 $\mid V T 15 M(320) \rightarrow V T 15 M(320) \Rightarrow>100 \%$ yang membeli VT15M juga membeli VT15

Gambar 10. Hasil Apriori 
hasil percobaan di atas dihasilkan dua aturan asosiasi yang terbentuk, dengan semua aturan yang lolos confidence(Isnain, Sihabuddin and Suyanto, no date; Alita, Fernando and Sulistiani, 2020). Dari percobaan di atas hanya dua aturan asosiasi yang akan di bentuk menajadi paket item promosi dan setiap paket item hanya berisi dua kuota dari tiga percobaan bahawa minimum support 90 dan minimum confidence 90 merupakan kombinasi yang bisa direkomendasikan oleh penulis untuk membuat kombinasi item yaitu : Vocer Tri 1,5GB dan Vocer Tri 1,5GB mini dengan nilai confidence 99.07\%

\section{SIMPULAN}

hasil analisa dan pengujian telah dilakukan ujicoba sistem sebanyak tiga kali mengunakan data transaksi. Konter G Cell selama periode bulan Desember 2019 sampai November 2020 (1 tahun) dengan merubah parameter minimum support dan minimum confidence. dua aturan asosiasi yang akan di bentuk menajadi paket item promosi dan setiap paket item hanya berisi dua kuota dari tiga percobaan bahawa minimum support 90 dan minimum confidence 90 merupakan kombinasi yang bisa direkomendasikan oleh penulis untuk membuat kombinasi item yaitu : Vocer Tri 1,5GB dan Vocer Tri 1,5GB mini dengan nilai confidence $99.07 \%$

\section{UCAPAN TERIMA KASIH}

Puji syukur penulis panjatkan kepada Allah SWT, karena atas berkat dan rahmat-Nya, penulis dapat menyelesaikan penelitian ini. Penulisan Penulis menyadari bahwa, tanpa bantuan dan bimbingan dari berbagai pihak, dari masa perkuliahan sampai pada penyusunan penelitian ini. Oleh karena itu, penulis mengucapkan terima kasih kepada:

1. Bapak Dr.H.M. Nasrullah Yusuf S.E, M.B.A., selaku Rektor Universitas Teknokrat Indonesia;

2. Bapak Dr. H. Mahathir Muhammad, S.E., M.M., selaku Dekan Fakultas Teknik dan Ilmu Komputer, Universitas Teknokrat Indonesia;

3. Ibu Dyah Ayu Megawaty, M. Kom. selaku Ketua Program S1 Informatika, Fakultas Teknik dan Ilmu Komputer, Universitas Teknokrat Indonesia;

\section{REFERENSI/DAFTAR PUSTAKA}

Alita, D., Fernando, Y. and Sulistiani, H. (2020) 'Implementasi Algoritma Multiclass SVM pada Opini Publik Berbahasa Indonesia di Twitter', Jurnal Tekno Kompak, 14(2), pp. 86-91.

Budiman, A., Wahyuni, L. S. and Bantun, S. (2019) 'Perancangan Sistem Informasi Pencarian Dan Pemesanan Rumah Kos Berbasis Web (Studi Kasus: Kota Bandar Lampung)', Jurnal Tekno Kompak, 13(2), pp. 24-30.

Eka, S., Putri, Y. and Surahman, A. (2020) 'PENERAPAN MODEL NAIVE BAYES UNTUK MEMPREDIKSI POTENSI PENDAFTARAN SISWA DI SMK TAMAN SISWA TELUK', 1(1), pp. 81-86.

Isnain, A. R., Sihabuddin, A. and Suyanto, Y. (no date) 'Bidirectional Long Short Term Memory Method and Word2vec Extraction Approach for Hate Speech Detection', IJCCS (Indonesian Journal of Computing and Cybernetics Systems), 14(2).

Iswandi, P., Permana, I. and Salisah, F. N. (2020) 'PENERAPAN ALGORITMA APRIORI PADA DATA TRANSAKSI PENJUALAN HYPERMART XYZ LAMPUNG UNTUK PENENTUAN TATA LETAK BARANG’, Jurnal Ilmiah Rekayasa dan Manajemen Sistem Informasi, 6(1), pp. 70-74.

Prasetyawan, P. et al. (2018) 'Classification of the Period Undergraduate Study Using Back-propagation Neural Network', Proceedings of the 2018 International Conference on Applied Engineering, ICAE 2018. doi: 10.1109/INCAE.2018.8579389.

Rahmawati, F. and Merlina, N. (2018) 'Metode Data Mining Terhadap Data Penjualan Sparepart Mesin Fotocopy Menggunakan Algoritma Apriori', PIKSEL : Penelitian Ilmu Komputer Sistem Embedded and Logic, 6(1), pp. 9-20. doi: 10.33558/piksel.v6i1.1390.

Setiawansyah, Sulistiani, H. and Darwis, D. (2020) 'Penerapan Metode Agile untuk Pengembangan Online Analytical Processing ( OLAP ) pada Data Penjualan ( Studi Kasus : CV Adilia Lestari )', Jurnal CoreIT, 6(1), pp. 50-56.

Sintaro, S., Surahman, A. and Prastowo, A. T. (2020) 'PENERAPAN WEB WALKERS SEBAGAI MEDIA INFORMASI UNTUK PERBANDINGAN MANUAL BREWING COFFEE DI INDONESIA', JSiI (Jurnal Sistem Informasi), 7(2), pp. 132-137.

Suryanata, M. G., Pane, D. H. and Hutasuhut, M. (2019) 'Implementasi Algoritma K-Means Dalam Mengukur Tingkat Kepuasan Siswa Terhadap Pelayanan Sekolah Studi Kasus Di Mts. S Nurul Amaliyah', J-SISKO TECH (Jurnal Teknologi Sistem Informasi dan Sistem Komputer TGD), 2(2), pp. 118-125. 